\title{
Effects of neuromedin-U on immature rat adrenocortical cells: In vitro and in vivo studies
}

\author{
AGNIESZKA ZIOLKOWSKA ${ }^{1}$, CARLO MACCHI ${ }^{2}$, MARCIN TREJTER $^{1}$, MARCIN RUCINSKI $^{1}$, \\ MAGDALENA NOWAK $^{1}$, GASTONE G. NUSSDORFER ${ }^{2 *}$ and LUDWIK K. MALENDOWICZ ${ }^{1}$ \\ ${ }^{1}$ Departiment of Histology and Embryology, Poznan School of Medicine, PL-60781 Poznan, Poland; \\ ${ }^{2}$ Department of Human Anatomy and Physiology, School of Medicine, University of Padua, I-35121 Padua, Italy
}

Received November 27, 2007; Accepted December 31, 2007

\begin{abstract}
Neuromedin U (NMU) is a brain-gut peptide, that in the peripheral organs and tissues acts via a $G$ protein-coupled receptor, called NMUR1. Reverse transcription-polymerase chain reaction showed the expression of NMUR 1 mRNA in either cortex and medulla or dispersed zona glomerulosa and zona fasciculata-reticularis cells of the immature rat adrenals. Accordingly, immunocytochemistry demonstrated the presence of NMUR1-like immunoreactivity in the cortex and medulla of immature adrenals. NMU8 administration to immature rats was found to raise aldosterone, but not corticosterone, plasma concentration, without altering adrenal growth. Conversely, the exposure to NMU8 markedly enhanced the proliferative activity of immature rat inner adrenocortical cells in primary in vitro culture, without significantly affecting their corticosterone secretion. Collectively, our findings suggest that adrenals of immature rats may be a target for circulating NMU. However, the physiological significance and relevance of the adrenal effects of NMU remain to be ascertained.
\end{abstract}

\section{Introduction}

Neuromedin-U (NMU) is a brain-gut peptide (23 amino acid residues in the rat) involved in the regulation of energy homeostasis and neuroendocrine functions (1-7; reviewed in ref. 8). NMU acts via two subtypes of G protein-coupled receptors, NMUR 1 and NMUR2, the former being the peripheral receptor and the latter the central one $(9,10)$.

As in the case of other peptides modulating energy homeostasis and food intake (e.g. NPY, cholecystokinin, galanin,

Correspondence to: Dr Ludwik K. Malendowicz, Poznan University of Medical Sciences, Department of Histology and Embryology, 6 Swiecicki Street, PL-60781 Poznan, Poland

E-mail:1km@amp.edu.pl

*Deceased

Key words: neuromedin U, NMUR1, adrenal gland, steroid secretion, cell prolifeation, immature rat leptin, orexins, beacon and NPW) (11-17), also NMU appears to regulate the hypothalamic-pituitary-adrenal (HPA) axis. The expression of NMU and $\mathrm{NMUR}_{2}$ was found in the hypothalamus and anterior pituitary (10,18-33), while in the adrenal glands only the expression of NMUR 1 was detected $(9,27-29,33,34)$. NMU has been shown to enhance c-fos expression in the hypothalamic paraventricular nucleus $(1,2,30,35)$, to increase $\mathrm{CRH}$ and vasopressin output from rat hypothalamic explants, and to stimulate ACTH and corticosterone secretion in the rat $(2,4,5,36-38)$.

The present study aimed to examine the expression of NMUR1 gene in the different components of immature rat adrenal gland, and to investigate the effect of NMU8, that contains the 7-amino acid $\mathrm{C}$-terminal active sequence of the native peptide (39), on the secretion and proliferative activity of cultured adrenocortical cells and adrenal cortex of immature rats.

\section{Materials and methods}

Animals and reagents. Immature male Wistar rats (21-day-old), bred in our laboratory facilities, were kept under a 14:10 h light-dark cycle (illumination onset at 6:00 a.m.) at $23^{\circ} \mathrm{C}$, and maintained on a standard diet and tap water ad libitum. The experimental protocol was approved by the local Ethics Committee for Animal Studies. NMU8 was purchased from Bachem (Bubbendorf, Switzerland), and vincristine from Gedeon-Richter (Budapest, Hungary). Rabbit anti-rat NMUR1 polyclonal primary antibody was provided by Alpha Diagnostic International (San Antonio, TX), and secondary peroxidaseconjugated anti-rabbit IgG polyclonal antibody by Amersham Biosciences (Piscataway, NJ). Dulbecco's modified minimum essential medium (DMEM)/nutrient mix and fetal calf serum (FCS) were provided by Gibco (Milan, Italy). All other chemicals and reagents were purchased from Sigma-Aldrich Corp. (St. Louis, MO).

Experimental design. Groups of rats $(\mathrm{n}=8)$ were given three subcutaneous injections of 1 or 4 nmoles/100 g body weight of NMU8 dissolved in $0.2 \mathrm{ml} 0.9 \%$ saline 24,16 and $8 \mathrm{~h}$ before sacrifice. Control rats $(n=8)$ received subcutaneous injections of saline. Three hours before sacrifice all rats were given an intraperitoneal injection of $0.1 \mathrm{mg} / 100 \mathrm{~g}$ body 
weight of vincristine. Animals were decapitated at 11:00 a.m., and their trunk blood was collected in the presence of EDTA $(1 \mathrm{mg} / \mathrm{ml})$. Plasma was separated and stored at $-36^{\circ} \mathrm{C}$ for hormone assay. Adrenals were removed, fixed in Bouin's solution and embedded in paraffin for metaphase-index assay and morphometric estimations. Adrenal glands of a number of untreated immature rats were removed, freed of pericapsular fat, fixed in Bouin's solution overnight and embedded in paraffin for immunocytochemistry (ICC). Other adrenals were decapsulated and halved: the cortex and medulla were separated, and dispersed adrenocortical cells were obtained by sequential enzymatic digestion and mechanical disaggregation. Specimens were frozen at $-80^{\circ} \mathrm{C}$ and used for reverse transcription (RT)-polymerase chain reaction (PCR) assay. Then, adrenal glands of further 12 immature rats were used to obtain primary inner adrenocortical cell cultures (see below).

In vitro culture. Dispersed inner adrenocortical cells were suspended in DMEM/nutrient mix (added with $1.125 \mathrm{~g} / 1$ sodium bicarbonate, $10 \%$ FCS and Sigma penicillinstreptomycin-fungizone mixture) and counted in a CASYcell counter (Model TT; Schaerfe System, Reutlingen, Germany). They were seeded at a density of $10^{4}$ cells/well into 24- or 96-well cluster dishes, and cultured for $96 \mathrm{~h}$ at $37^{\circ} \mathrm{C}$, the medium being changed every $24 \mathrm{~h}$ (40). At day 4 of culture, cells were incubated for an additional $24 \mathrm{~h}$ with NMU8 $\left(10^{-8}\right.$ or $\left.10^{-6} \mathrm{M}\right)$. As positive control, a group of cultures was incubated in the presence of $10^{-8} \mathrm{M} \mathrm{ACTH}$. Culture medium was collected and stored at $-36^{\circ} \mathrm{C}$.

$R T-P C R$. Total RNA was extracted from the frozen specimens, and reverse transcribed to cDNA (41-44). PCR was carried out, as previously detailed (45-47), in a Roche LightCycler 2.0, using the following primers: NMUR 1 sense (481-500), 5'-GCC-ATC-TGG-GTC-TTC-GCT-AT-3' and antisense (797-816) 5'-CAC-CTG-TCT-GCG-TTC-CCT-AT-3' (336 bp; accession number, AF-242873). The PCR program was: denaturation step at $94^{\circ} \mathrm{C}$ for $10 \mathrm{~min}$, followed by 35 cycles of three amplification steps $\left(94^{\circ} \mathrm{C}\right.$ for $30 \mathrm{sec}$, annealing at $55^{\circ} \mathrm{C}$ for $60 \mathrm{sec}$ and extension at $68^{\circ} \mathrm{C}$ for $120 \mathrm{sec}$ ). To rule out the possibility of amplifying genomic DNA, one PCR was performed without prior RT of the RNA. Detection of the PCR amplification products was carried out by size fractionation on $2 \%$ agarose gel electrophoresis.

ICC. Paraffin-embedded adrenals were cut, and the sections $(6 \mu \mathrm{m})$ were incubated with the primary anti-NMUR 1 antibody (1:100 dilution) for $60 \mathrm{~min}$ at $4^{\circ} \mathrm{C}$. After washing, sections were incubated overnight at $37^{\circ} \mathrm{C}$ with the secondary peroxidase-conjugated antibody, and peroxidase activity was detected using the DAB technique (Dako Liquid DAB substrate-chromogen system; Dako, Glostrup, Denmark). When necessary, nuclei were counterstained with hematoxylin. Negative controls were carried out by similarly treating adjacent sections and omitting the primary antibody (48).

Metaphase index and morphometry. Sections $(6 \mu \mathrm{m})$ were stained with hematoxylin and eosin, and metaphase index (number of vincristine-arrested metaphase cells per 1,000 cells) was calculated at a magnification of $x 400$, by counting 5,000

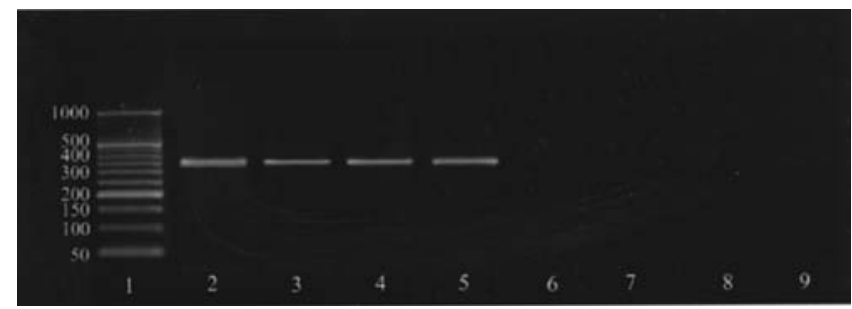

Figure 1. Ethidium bromide-stained $2 \%$ agarose gel showing cDNA amplified with rat NMUR1 specific primers from exemplary adrenal cortex (2), adrenal medulla (3), dispersed zona glomerulosa cells (4) and dispersed zona fasciculata-reticularis cells (5) of immature rats. Respective negative controls (no RT of the RNA) are shown in lanes 6-9. Lane 1 was loaded with 200 ng of a DNA size marker (50 bp DNA Ladder; MBI Fermentas, Vilnius, Lithuania).
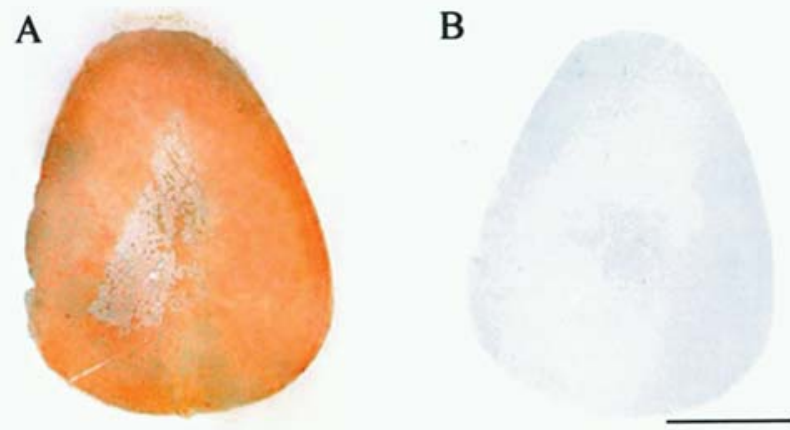

Figure 2. ICC localization of NMUR1-like immunoreactivity in the adrenal gland of immature rats. Staining is more intense in the cortex than in the adrenal medulla (A). Negative control was obtained by omitting the primary antibody (B). Magnification as defined by bar, $1 \mathrm{~mm}$.

cells in the outer cortex of each adrenal (49). The number of nuclei of adrenocortical cells was counted at a magnification of $\mathrm{x} 400$ in 50 fields (area, $0.003 \mathrm{~mm}^{2}$ ) of the outer cortex of each adrenal, and the number of nuclei per $\mathrm{mm}^{2}$ was calculated.

Cell proliferation assay. Proliferation rate of cultured adrenocortical cells was assayed by the EZ4U non-radioactive cell proliferation and cytotoxic assay of Biomedica (Vienna, Austria), as detailed earlier $(40,50)$. Briefly, cultures were incubated for the last $5 \mathrm{~h}$ with EZAU and formazan production, which is linearly related to the cell number, was assayed by measuring absorbance at $490 \mathrm{~nm}$ wavelength in a microplate autoreader EL13 (Bio-Tek Instruments, Winooski, VT).

Hormone assay. Aldosterone and corticosterone were extracted from plasma, and corticosterone from culture incubation media, and measured by RIA, as detailed earlier $(51,52)$. Aldosterone RIA: sensitivity, $5 \mathrm{pg} / \mathrm{ml}$, intra- and interassay CVs, 5 and 7\%, respectively. Corticosterone RIA: sensitivity, $50 \mathrm{pg} / \mathrm{ml}$, intra- and interassay CVs, 7 and 9\%, respectively.

Statistics. Data were expressed as means \pm SEM, and the statistical significance of the differences among experimental groups was estimated using ANOVA, followed by the Duncan's multiple range test. 


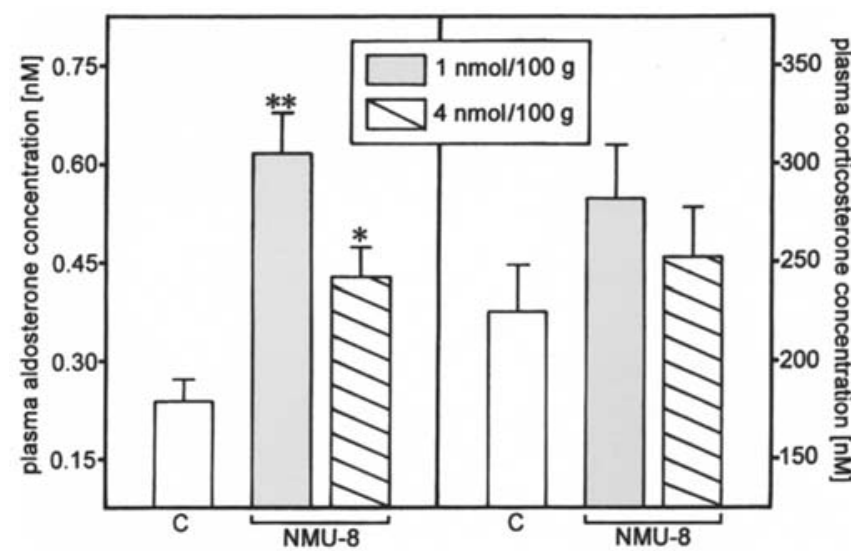

Figure 3. Effects of NMU8 administration on aldosterone and corticosterone plasma concentrations in immature rats. Bars are means \pm SEM $(n=8)$. ${ }^{*} \mathrm{P}<0.05$ and ${ }^{* *} \mathrm{P}<0.01$ from control (C) rats.

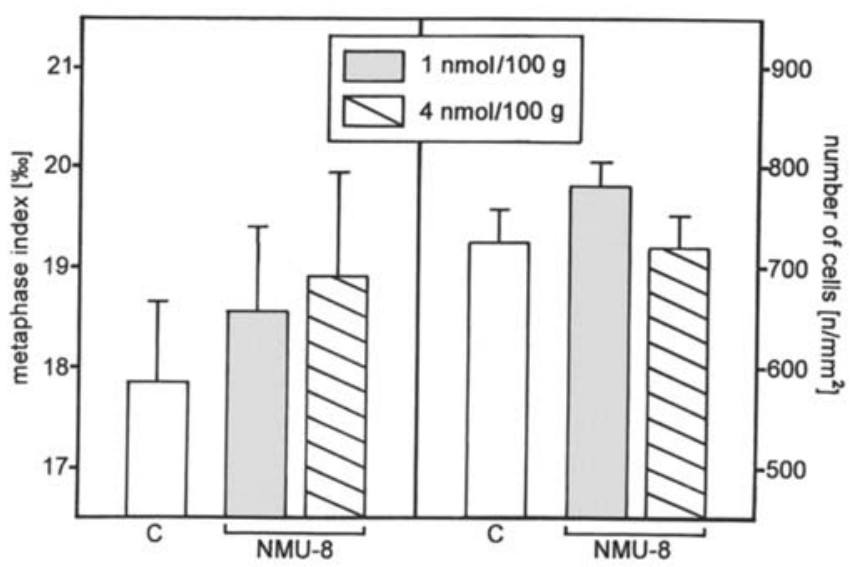

Figure 4. Lack of effect of NMU8 administration on the growth of the adrenal in immature rats. Bars are means $\pm \operatorname{SEM}(n=8)$.

\section{Results}

RT-PCR detected the expression of NMUR1 mRNA in either the cortex and medulla or in dispersed zona glomerulosa and zona fasciculata-reticularis cells of the immature rat adrenal gland (Fig. 1). ICC revealed the presence of NMUR1-like immunoreactivity in the immature rat adrenals, which was intense in the cortex and weak in the medulla (Fig. 2).

NMU8 administration to immature rats raised plasma aldosterone, but not corticosterone, concentrations (Fig. 3). Neither metaphase index nor the number of adrenocortical cells per unit area were affected (Fig. 4).

As expected, ACTH markedly increased corticosterone secretion from and decreased proliferation rate of cultured adrenocortical cells of immature rats. NMU8 did not alter corticosterone output from cultured cells (Fig. 5), but significantly increased their proliferation rate (Fig. 6).

\section{Discussion}

Our present RT-PCR and ICC studies clearly demonstrate the expression of NMUR 1 as mRNA and protein in the cortex of

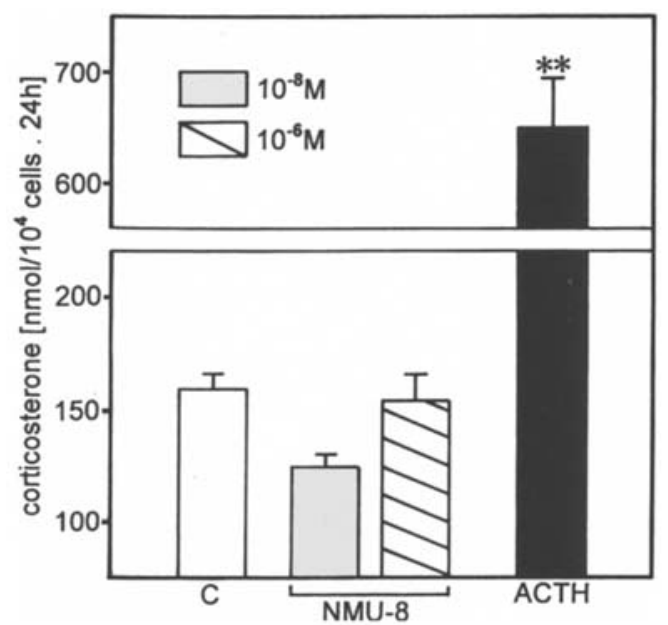

Figure 5. Effects of NMU8 and ACTH on corticosterone secretion from immature rat inner adrenocortical cells in primary in vitro culture. Bars are means \pm SEM $(n=4),{ }^{* *} \mathrm{P}<0.01$ from control $(C)$ cultures.

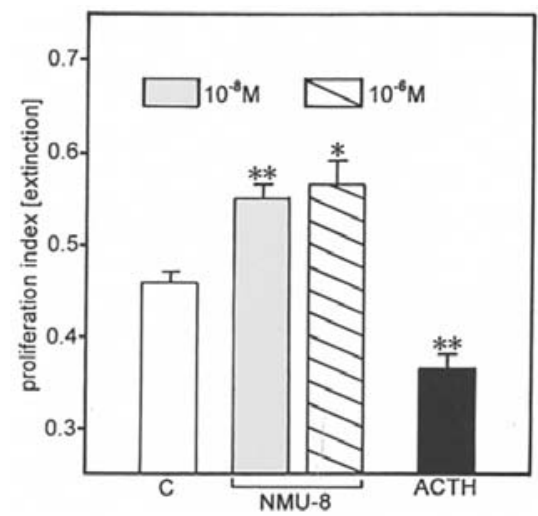

Figure 6. Effects of NMU8 and ACTH on the proliferative activity of immature rat inner adrenocortical cells in primary in vitro culture. Bars are means \pm SEM $(n=4) .{ }^{*} \mathrm{P}<0.05$ and ${ }^{* *} \mathrm{P}<0.01$ from control $(\mathrm{C})$ cultures.

immature rat adrenals, thereby confirming earlier findings obtained in adult animals $(9,27-29,33,34)$. Moreover, the detection of NMUR1 mRNA in dispersed zona glomerulosa and zona fasciculata-reticularis cells rules out the possibility that the expression was due to the presence in the specimens assayed of the non-parenchymal components of the gland (connective tissue and capillaries). In contrast, they strongly suggest the involvement of NMU in the physiological regulation of the biological activity of immature rat adrenocortical cells. It has been suggested that NMU exerts its biological effects mainly via autocrine-paracrine mechanisms (53). However, the expression of NMU gene was not detected in the rat adrenals (33). Phoenix Pharmaceuticals has recently made available kits for NMU assay, that showed that this peptide may attain in human plasma concentrations of $\sim 10^{-8} \mathrm{M}$ (30 pg/ml) (33). Hence, it is reasonable to conceive that NMU may activate adrenocortical NMUR1 acting as a true circulating hormone.

Our in vivo and in vitro experiments gave rather contrasting results. At $10^{-8}$ and $10^{-6} \mathrm{M}$ concentrations, NMU8 did not affect corticosterone secretion from ACTH-responsive inner 
adrenocortical cells in primary culture, but did stimulate their proliferative activity. In contrast, the repeated subcutaneous administration of 1 and 4 nmoles of NMU8, which can give rise to a blood concentration ranging from $10^{-8}$ to $10^{-7} \mathrm{M}$ (54), was found to increase blood aldosterone, but not the corticosterone level, without significantly altering the proliferative activity of adrenocortical cells. The obvious differences in the biology between in vivo and in vitro cultured adrenocortical cells may explain these discrepancies.

In vivo findings do not agree with the earlier contention that NMU8 stimulates HPA axis in the rat (see Introduction): neither the ACTH-dependent corticosterone secretion nor adrenal growth were enhanced. Probably the regulation of adrenal function of immature rats differs from that of adult animals. The growth of adrenals connected with the body growth seems to be mainly mediated by the GH-IGF/IGFB system (55), that could not be influenced by exogenous NMU. The NMU8-induced rise in aldosterone plasma level could ensue from either a direct NMUR1-mediated stimulating action on zona glomerulosa (but not zona fasciculatareticularis) cells or the reported enhanced release of vasopressin (3), which is well known to be a potent aldosterone secretagogue (56). The refractoriness of zona fasciculata-reticularis cell secretion to NMU8 may explain the lack of effect of this peptide on corticosterone secretion from inner adrenocorticalcell primary cultures. However, these cells, which are provided with NMUR1, display a clear-cut proliferative response to NMU8. This observation is not surprising because the growth behavior of adrenocortical cells cultured in vitro profoundly differs from that of their in vivo counterpart, as evidenced by the fact that ACTH stimulates adrenocortical cell growth in vivo, but inhibits proliferation of adrenocortical cells cultured in vitro (57).

In conclusion, our present study demonstrates the presence of NMUR 1 in immature rat adrenocortical cells, and suggests that NMU may affect their biological activity via an endocrine route. However, the physiological significance and relevance of the adrenal effects of NMU remain to be ascertained.

\section{References}

1. Niimi M, Murao K and Taminato T: Central administration of neuromedin $U$ activates neurons in ventrobasal hypothalamus and brainstem. Endocrine 16: 201-206, 2001.

2. Ozaki Y, Onaka T, Nakazato M, Saito J, Kanemoto K, Matsumoto T and Ueta Y: Centrally administered neuromedin $\mathrm{U}$ activates neurosecretion and induction of C-Fos messenger ribonucleic acid in the paraventricular and supraoptic nuclei of rat. Endocrinology 143: 4320-4329, 2002.

3. Wren AM, Small CJ, Abbott CR, Jethwa PH, Keneddy AR, Murphy KG, Stanley SA, Zollner AN, Ghatei MA and Bloom SR: Hypothalamic actions of neuromedin U. Endocrinology 143: 4227-4234, 2002

4. Thompson EL, Murphy KG, Todd JF, Martin NM, Small CJ, Ghatei MA and Bloom SR: Chronic administration of NMU into the paraventricular nucleus stimulates the HPA axis but does not influence food intake or body weight. Biochem Biophys Res Commun 323: 65-71, 2004.

5. Ueta Y, Ozaki Y and Saito J: Novel G-protein coupled receptor ligands and neurohypophysial hormones. J Neuroendocrinol 16 : 378-382, 2004.

6. Jethwa PH, Smith KL, Small CJ, Abbott CR, Darch SJ, Murphy KG, Seth A, Semjonous NM, Pate SR, Todd JF, Ghatei MA and Bloom SR: Neuromedin U partially mediates leptin-induced hypothalamo-pituitary-adrenal (HPA) stimulation and has a physiological role in the regulation of the HPA axis in the rat. Endocrinology 147: 2886-2892, 2006.
7. Novak CM, Zhang M and Levine JA: Neuromedin U in the paraventricular and arcuate hypothalamic nuclei increases non-exercise activity thermogenesis. J Neuroendocrinol 18: 594-601, 2006.

8. Jethwa PH, Small CJ and Blood SR: Neuromedin U (NMU): brain peptide. In: Handbook of Biologically Active Peptides. Kastin AJ (ed). Academic Press, Burlington, pp745-752, 2006.

9. Raddatz R, Wilson AE, Artymyshyn R, Bonini JA, Borowsky B, Boteju LW, Zhou SQ, Kouranova EV, Nagorny R, Guevarra MS, Dai M, Lerman GS, Vaysse PJ, Branchek TA, Gerald C, Forray C and Adham N: Identification and characterization of two neuromedin $U$ receptors differentially expressed in peripheral tissues and the central nervous system. J Biol Chem 275: 32452-32459, 2000

10. Graham ES, Turnbull Y, Fotheringham P, Nilaweera K, Mercer JG, Morgan PJ and Barrett P: Neuromedin U and neuromedin $U$ receptor-2 expression in the mouse and rat hypothalamus: effects of nutritional status. J Neurochem 87 : 1165-1173, 2003.

11. Spinazzi R, Andreis PG and Nussdorfer GG: Neuropeptide Y and Y-receptors in the autocrine-paracrine regulation of adrenal gland under physiological and pathophysiological conditions. Int J Mol Med 15: 3-13, 2005.

12. Nussdorfer GG, Spinazzi R and Mazzocchi G: Cholecystokinin (CCK) and adrenal cortex secretion. Vitam Horm 71: 433-453, 2005.

13. Rucinski M, Spinazzi R, Ziolkowska A, Nussdorfer GG and Malendowicz LK: Effects of beacon on the rat pituitaryadrenocortical axis response to stress. Int J Mol Med 16: 297-299, 2005.

14. Spinazzi R, Andreis PG, Rossi GP and Nussdorfer GG: Orexins in the regulation of the hypothalamic-pituitary-adrenal axis. Pharmacol Rev 58: 46-57, 2006.

15. Hochól A, Tortorella C, Rucinski M, Ziolkowska A, Nussdorfer GG and Malendowicz LK: Effects of neuropeptides $\mathrm{B}$ and $\mathrm{W}$ on the rat pituitary-adrenocortical axis: in vivo and in vitro studies. Int J Mol Med 19: 207-211, 2007.

16. Malendowicz LK, Rucinski M, Belloni AS, Ziolkowska A and Nussdorfer GG: Leptin and the regulation of the hypothalamicpituitary-adrenal axis. Int Rev Cytol 263: 65-104, 2007.

17. Tortorella C, Neri G and Nussdorfer GG: Galanin in the regulation of the hypothalamic-pituitary-adrenal axis. Int J Mol Med 19: 639-647, 2007

18. Domin J, Ghatei MA, Chohan P and Bloom SR: Characterization of neuromedin U like immunoreactivity in rat, porcine, guineapig and human tissue extracts using a specific radioimmunoassay. Biochem Biophys Res Commun 140: 1127-1134, 1986.

19. Domin J, Ghatei MA, Chohan P and Bloom SR: Neuromedin $\mathrm{U}$ : a study of its distribution in the rat. Peptides 8: 779-784, 1987.

20. Honzawa M, Sudoh T, Minamino N, Tohyama M and Matsuo H: Topographic localization of neuromedin U-like structures in the rat brain: an immunohistochemical study. Neuroscience 23: 1103-1122, 1987.

21. Ballesta J, Carlei F, Bishop AE, Steel JH, Gibson SJ, Fahey M, Hennessey R, Domin J, Bloom SR and Polak JM: Occurrence and developmental pattern of neuromedin U-immunoreactive nerves in the gastrointestinal tract and brain of the rat. Neuroscience 3: 797-816, 1988.

22. Steel JH, Van Noorden S, Ballesta J, Gibson SJ, Ghatei MA, Burrin J, Leonhardt U, Domin J, Bloom SR and Polak JM: Localization of $7 \mathrm{~B} 2$, neuromedin $\mathrm{B}$, and neuromedin $\mathrm{U}$ in specific cell types of rat, mouse, and human pituitary, in rat hypothalamus and in 30 human pituitary and extrapituitary tumors. Endocrinology 122: 270-282, 1988.

23. Timmermans JP, Scheuermann DW, Stach W, Adriaensen D, De Groodt-Lasseel MHA and Polak JM: Neuromedin U-immunoreactivity in the nervous-system of the small-intestine of the pig and its co-existence with substance-P and CGRP. Cell Tissue Res 258: 331-337, 1989.

24. Cimini V, Van Noorden S, Timson CM and Polak JM: Modulation of galanin and neuromedin U-like immunoreactivity in rat corticotropes after alteration of endocrine status. Cell Tissue Res 272: 137-146, 1993.

25. Fujii R, Hosoya M, Fukusami S, Kazamata Y, Habata Y, Hinuma $\mathrm{S}$, Onda $\mathrm{H}$, Nishimura $\mathrm{O}$ and Fujino $\mathrm{M}$ : Identification of neuromedin $U$ as the cognate ligand of the orphan $G$ protein-coupled receptor FM-3. J Biol Chem 275: 21068-21074, 2000 . 
26. Hosoya M, Moriya T, Kawamata Y, Ohkubo S, Fujii R, Matsui H, Shintani Y, Fukusumi S, Habata Y, Hinuma S, Onda H, Nishimura $\mathrm{O}$ and Fujino M: Identification and functional characterization of a novel subtype of neuromedin $U$ receptor. J Biol Chem 275: 29528-29532, 2000.

27. Howard AD, Wang R, Pong SS, Mellin TN, Strack A, Guan XM, Zeng Z, Williams DL Jr, Feighner SD, Nunes CN, Murphy B, Stair JN, Yu H, Jiang Q, Clements MK, Tan CP, McKee KK, Hreniuk DL, McDonald TP, Lynch KR, Evans JF, Austin CP, Caskey CT, Van der Ploeg LH and Liu Q: Identification of receptors for neuromedin $\mathrm{U}$ and its role in feeding. Nature 406: 70-74, 2000.

28. Szekeres PG, Muir AI, Spinage LD, Miller JE, Butler SI, Smith A, Rennie GL, Murdock PR, Fitzgerald LR, Wu H, McMillan LJ, Guerrera S, Vawter L, Elshourbagy NA, Mooney JL, Bergsma DJ, Wilson S and Chambers JK: Neuromedin $U$ is a potent agonist at the orphan $\mathrm{G}$ protein-coupled receptor FM3. J Biol Chem 275: 20247-20250, 2000.

29. Westfall TD, McCafferty GP, Pullen M, Gruver S, Sulpizio AC, Aiyar VN, Disa J, Contino LC, Mannan IJ and Hieble JP: Characterisation of neuromedin $U$ effects in canine smoothmuscle. J Pharmacol Exp Ther 301: 987-992, 2001.

30. Ivanov TR, Lawrence CB, Stanley PJ and Luckman SM: Evaluation of neuromedin $U$ actions in energy homeostasis and pituitary function. Endocrinology 143: 3813-3821, 2002.

31. Qiu DL, Chu CP, Shirasaka T, Nabekura T, Kunitake T, Kato K, Nakazato M, Katoh T and Kannan H: Neuromedin U depolarizes rat hypothalamic paraventricular nucleus neurons in vitro by enhancing IH channel activity. J Neurophysiol 90: 843-850, 2003.

32. Qiu DL, Chu CP, Tsukino H, Shirasaka T, Nakao H, Kato K, Kunitake T, Katoh T and Kannan H: Neuromedin U receptor-2 mRNA and HCN channels mRNA expression in NMU-sensitive neurons in rat hypothalamic paraventricular nucleus. Neurosci Lett 374: 69-72, 2005

33. Rucinski M, Ziolkowska S, Neri G, Trejter M, Zemleduch T, Tyczewska M, Nussdorfer GG and Malendowicz LK: Expression of neuromedin $\mathrm{S}$ and $\mathrm{U}$ and their receptors in the hypothalamus and endocrine glands of the rat. Int J Mol Med 20: 255-259, 2007.

34. Hedrick JA, Morse K, Shan L, Qiao X, Pang L, Wang S, Laz T, Gustafson EL, Bayne M and Monsma JF: Identification of a human gastrointestinal tract and immune system receptor for the peptide neuromedin U. Mol Pharmacol 58: 870-875, 2000.

35. Yokota M, Ozaki Y, Sakamoto F, Yamada S, Saito J, Fujihara H and Ueta Y: Fos expression in CRF-containing neurons in the rat paraventricular nucleus after central administration of neuromedin U. Stress 7: 109-112, 2004

36. Malendowicz LK, Andreis PG, Markowska A, Nowak M, Warchol JB, Neri G and Nussdorfer GG: Effects of neuromedin U-8 on the secretory activity of the rat adrenal-cortex: evidence for an indirect action requiring the presence of the zona medullaris. Res Exp Med 194: 69-79, 1994.

37. Malendowicz LK, Nussdorfer GG, Markowska A, Tortorella C, Nowak M and Warchol JB: Effects of neuromedin-U (NMU)-8 on the rat hypothalamo-pituitary-adrenal axis: evidence of a direct effect of NMU-8 on the adrenal-gland. Neuropeptides 26: 47-53, 1994.

38. Malendowicz LK: Role of neuromedins in the regulation of adrenocortical function. Horm Metab Res 30: 374-384, 1998.

39. Minamino N, Kangawa K and Matsuo M: Neuromedin U-8 and U-25: novel uterus stimulating and hypertensive peptides identified in porcine spinal cord. Biochem Biophys Res Commun 130: 1078-1085, 1985.

40. Ziolkowska A, Tortorella C, Nussdorfer GG, Rucinski M, Majchrzak M and Malendowicz LK: Accumulation of steroidogenic acute regulatory protein mRNA and decrease in the secretory and proliferative activity of rat adrenocortical cells in the presence of proteasome inhibitors. Int J Mol Med 17: 865-868, 2006.
41. Albertin G, Ruggero M, Guidolin D and Nussdorfer GG: Gene silencing of human RAMP2 mediated by short-interfering RNA. Int J Mol Med 18: 531-535, 2006.

42. Carraro G, Albertin G, Aragona F, Forneris M, Casale V, Spinazzi R and Nussdorfer GG: Age-dependent decrease in the ghrelin gene expression in the human adrenal cortex: A real-time PCR study. Int J Mol Med 17: 319-321, 2006.

43. Spinazzi R, Albertin G, Nico B, Guidolin D, Di Liddo R, Rossi GP, Ribatti D and Nussdorfer GG: Urotensin-II and its receptor (UT-R) are expressed in rat brain endothelial cells, and urotensin-II via UT-R stimulates angiogenesis in vivo and in vitro. Int J Mol Med 18: 1107-1112, 2006.

44. Rossi GP, Sticchi D, Giuliani L, Bernante P, Zavattero S, Pessina AC and Nussdorfer GG: Adiponectin receptor expression in the human adrenal cortex and aldosterone-producing adenomas. Int J Mol Med 17: 975-980, 2006.

45. Albertin G, Casale V, Ziolkowska A, Spinazzi R, Malendowicz LK, Rossi GP and Nussdorfer GG: Urotensin-II and UII-receptor expression and function in the rat adrenal cortex. Int J Mol Med 17: $1111-1115,2006$

46. Malendowicz W, Rucinski M, Belloni AS, Ziolkowska A, Nussdorfer GG and Kwias Z: Real-time PCR analysis of leptin and leptin receptor expression in the rat prostate, and effects of leptin on prostatic acid phosphatase release. Int J Mol Med 18: 1097-1100, 2006.

47. Rucinski M, Ziolkowska A, Hochol A, Pucher A, Macchi C, Belloni AS, Nussdorfer GG and Malendowicz LK: Estradiol and resveratrol stimulating effect on osteocalcin, but not osteonectin and collagen-1. gene expression in primary culture of rat calvarial osteoblast-like cells. Int J Mol Med 18: 565-570, 2006.

48. Hochol A, Belloni AS, Rucinski M, Ziolkowska A, Di Liddo R, Nussdorfer GG and Malendowicz LK: Expression of neuropeptides $\mathrm{B}$ and $\mathrm{W}$ and their receptors in endocrine glands of the rat. Int J Mol Med 18: 1101-1106, 2006.

49. Ziolkowska A, Rucinski M, Tyczewska M, Belloni AS, Nowak M, Nussdorfer GG and Malendowicz LK: Downregulation of the beacon gene expression in the regenerating rat adrenal cortex. Peptides 27: 3216-3219, 2006

50. Malendowicz LK, Rebuffat P, Tortorella C, Nussdorfer GG, Ziolkowska A and Hochol A: Effects of met-enkephalin on cell proliferation in different models of adrenocortical-cell growth. Int J Mol Med 15: 841-845, 2005.

51. Hochol A, Albertin G, Nussdorfer GG, Spinazzi R, Ziolkowska A, Rucinski M and Malendowicz LK: Effects of neuropeptides B and $\mathrm{W}$ on the secretion and growth of rat adrenocortical cells. Int J Mol Med 14: 843-847, 2004.

52. Spinazzi R, Petrelli L, Guidolin D, Carraro G, Casale V, Tortorella C, Neri G, Albertin G, Andreis PG and Nussdorfer GG: In vitro culture on Matrigel favors the long-term maintenance of rat zona glomerulosa-cell differentiated phenotype. Int J Mol Med 17: 1101-1110, 2006.

53. Mori K, Miyazato M, Ida T, Murakami N, Serino R, Ueta Y, Kojima $\mathrm{M}$ and Kangawa K: Identification of neuromedin $\mathrm{S}$ and possible role in the mammalian circadian oscillator system. EMBO J 24: 325-335, 2005.

54. Rebuffat P, Belloni AS, Musajo FG, Rocco S, Markowska A, Mazzocchi G and Nussdorfer GG: Evidence that endogenous somatostatin (SRIF) exerts an inhibitory control on the function and growth of rat adrenal zona glomerulosa. The possible involvement of zona medullaris as a source of endogenous SRIF. J Steroid Biochem Mol Biol 48: 353-360, 1994.

55. Dallman MF: Control of adrenocortical growth in vivo. Endocr Res 10: 213-242, 1985

56. Nussdorfer GG: Paracrine control of adrenal cortical function by medullary chromaffin cells. Pharmacol Rev 48: 495-530, 1996

57. Nussdorfer GG: Cytophysiology of the adrenal cortex. Int Rev Cytol 98: 1-405 1986. 